\title{
THE MECHANISM OF GLUTATHIONE DESTRUCTION AND PROTECTION IN DRUG-SENSITIVE AND NON- SENSITIVE ERYTHROCYTES. IN VITRO STUDIES
}

\author{
By ERNEST BEUTLER, MELBA ROBSON, AND ELLEN BUTTENWIESER \\ (From the Argonne Cancer Research Hospital and the Department of Medicine, The University \\ of Chicago, Chicago, Ill.)
}

(Submitted for publication August 25, 1956; accepted December 20, 1956)

When the anti-malarial drug primaquine or certain related aniline derivatives, such as sulfanilamide and acetanilid, are administered to sensitive individuals, an acute hemolytic anemia develops $(1,2)$. Such sensitivity is very rare among Caucasians but occurs in approximately 10 per cent of American Negroes (3). Investigation of this phenomenon by means of red cell survival studies established that sensitivity to the hemolytic action of primaquine was due to an intrinsic abnormality of the red blood cells of sensitive subjects (4). Extensive studies of these erythrocytes demonstrated, however, that sensitivity to these drugs is not merely another manifestation of a previously described red cell abnormality. It was shown, for example, that the defect of drug-sensitive cells is not associated with any alteration in fragility to chemical, osmotic and mechanical lysis, electrophoretic mobility of the hemoglobin, susceptibility to alkali denaturation, antigenic pattern, or Coomb's test (5).

When the drug was administered continually to a sensitive individual, hemolysis stopped after the initial hemolytic crisis and the blood counts returned spontaneously to normal (6). By labeling red cells with a limited age span with $\mathrm{Fe}^{59}$ we were able to explain this phenomenon, demonstrating that only the older members of the red cell population were destroyed through the action of drug (7). This finding led us to suggest that primaquine sensitivity might be due to a deficiency in an enzyme system that decreased in activity as the red cell aged, a condition which is known to be met by a number of red cell enzymes (8).

We therefore examined various enzyme systems in red cells, which for one reason or another might be implicated in drug sensitivity. These studies indicated that sensitivity to these drugs was not due to a defect in catalase, carbonic anhydrase, or cholinesterase activity. They also demonstrated that glycolysis was sufficiently normal to result in normal incorporation of radioactive phosphorus and that blocking glycolysis with sodium fluoride did not cause non-sensitive cells to behave like sensitive cells in the in vitro study system we had developed (8). Measurement of the reduced glutathione (GSH) content of drug-sensitive cells revealed that they were deficient in this compound (8). When the GSH content of sensitive cells was measured during drug administration it was found that an abrupt fall in the average red cell GSH concentration preceded the major portion of the hemolytic episode, but that as hemolysis progressed, the average red cell GSH returned to pre-treatment levels (9). This suggested that GSH was destroyed in the older, sensitive red cells and that subsequently the GSH deficient cells were removed from the circulation. Whether the fall in GSH level is the direct cause of the in vivo destruction of the red cell or merely one manifestation of a large number of incidental drug-induced alterations in the chemistry of the cell is a question that still requires an answer. However, it seemed reasonable that GSH might play an important role in drug-induced hemolyis, and that therefore further study of the destruction of red cell glutathione was warranted.

\section{MATERIALS AND METHODS}

Blood donors. Most individuals designated as "sensitive" or "non-sensitive" had been given $30 \mathrm{mg}$. of primaquine daily to establish their reaction to the drug at some time prior to the studies reported in this paper. None had received drug for at least several weeks and some had not been exposed to it for several years. ${ }^{1}$ In

1 The authors are indebted to Drs. Alf S. Alving, C. Larkin Flanagan, and Paul Carson for making most of these blood samples available for study. 
some instances it was necessary to use red cells from a donor whose sensitive status was established by in vitro testing, using the two methods that we have described $(10,11)$. In experiments using these cells, they are referred to as "sensitive (by test)." Because of the negligible incidence of drug sensitivity among Caucasians (3) samples from Caucasian donors were regarded as being non-sensitive and are referred to as being "nonsensitive (Caucasian)."

GSH stability test. The method of testing the stability of red cell glutathione has been presented in detail elsewhere (11). The GSH content of the blood sample was measured, and 1-ml. aliquots of the well-oxygenated sample were added to test tubes containing $5 \mathrm{mg}$. of acetylphenylhydrazine. After 2 hours' incubation at $37^{\circ} \mathrm{C}$, GSH determinations were carried out on the incubated aliquots.

Glutathione determinations. Reduced glutathione (GSH) determinations were carried out by our modification (11) of the method of Grunert and Phillips (12). Total glutathione (GSH plus oxidized glutathione (GSSG)) was determined by electrolytically reducing a 10-ml. aliquot of metaphosphoric acid filtrate obtained by this method. Electrolytic reduction was carried out over mercury in a $4.6 \mathrm{~cm}$.-diameter beaker for $30 \mathrm{~min}$ utes at $40 \mathrm{ma}$. according to the method of Dohan and Woodward (13).

Hemoglobin solutions. Destromatized hemoglobin solutions were prepared by a modification of the method of Drabkin (14). Red cells washed three times with 0.9 per cent sodium chloride solution were shaken with 1 volume of water and 0.4 volumes of toluene for onehalf hour and then centrifuged. The hemoglobin layer was filtered. The hemoglobin solution was then dialyzed in 18/32 inch Visking cellophane casing against large volumes of distilled water at $4^{\circ} \mathrm{C}$ for 72 hours. Erythrocytes from a non-sensitive (Caucasian) donor were used.

a. Methemoglobin was prepared by suspending the red cells in 1 per cent sodium nitrite for one-half hour before washing with saline.

b. Cyanmethemoglobin was prepared by adding 0.1 per cent sodium cyanide to the red cells suspended in 1 per cent sodium nitrite before washing with saline.

c. Carboxyhemoglobin was formed by passing carbon monoxide through the dialyzed, destromatized hemoglobin solution.

d. "Acetylphenylhydrazine-modified hemoglobin" was formed by incubating 1-ml. aliquots of blood with 5 mg. acetylphenylhydrazine before washing with sodium chloride solutions. Dialysis was carried out for 48 hours. Although it seemed reasonable that this procedure would remove unbound acetylphenylhydrazine from the solution, no direct tests for retained acetylphenylhydrazine have been carried out. Measurements of absorption spectra were carried out in the Beckman Direct Transmittance Recording Spectrophotometer, Model $\mathrm{DK}$, in the range 325 to $800 \mathrm{~m} \mu$.
Substrates and coenzymes. Reduced glutathione, the barium salts of glucose-6-phosphate, fructose-6-phosphate and ribose-5-phosphate, inosine, adenosine triphosphate (ATP), ribose, and fructose diphosphate were obtained from the Nutritional Biochemicals Corporation. The barium salt of 6-phosphogluconic acid and diphosphopyridine nucleotide (DPN) were obtained from Delta Chemical Works. Methylene blue was obtained from the National Aniline Division, Allied Chemical \& Dye Corporation. Sodium fumarate was prepared by neutralizing fumaric acid, recrystallized from the practical grade, Eastman Kodak, with sodium hydroxide to a $\mathrm{pH}$ of 7.0. Sodium pyruvate and sodium malate were prepared in the same fashion from pyruvic acid, kindly supplied by Dr. E. S. G. Barron, and from malic acid, obtained from the Pfanstiel Chemical Company. Sodium lactate was prepared by heating lactic acid, Baker Chemical Company, with an excess of sodium hydroxide at $80^{\circ} \mathrm{C}$ for 20 minutes, then adjusting the $\mathrm{pH}$ to 7.0 with hydrochloric acid. Nicotinamide, U.S.P., was obtained from the New York Quinine Chemical Company. Reduced triphosphopyridine nucleotide (TPNH) and reduced DPN (DPNH) were obtained from Sigma Chemical Company.

Sodium salts were prepared from barium salts immediately prior to use. One and one-half $\mathrm{ml}$. of distilled water

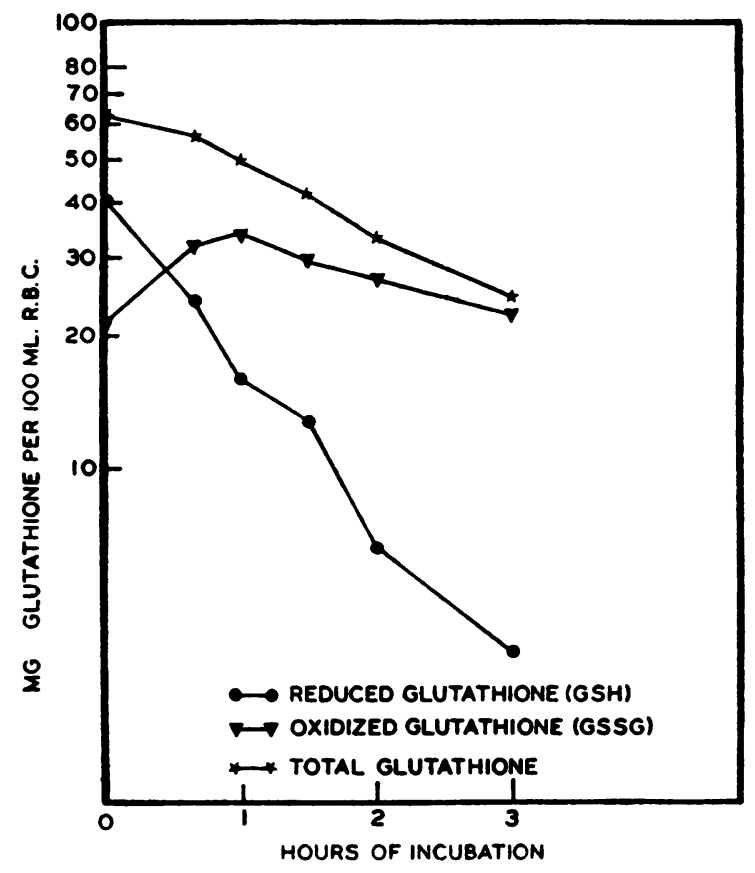

Fig. 1. The Fate of the GSH of Drug-Sensitive Red Cells Incubated with ACETYLPhenYlhydRazine

One-ml. aliquots of blood from a sensitive (by test) subject were incubated with $5 \mathrm{mg}$. acetylphenylhydrazine. As the GSH concentration fell there was a rise in the GSSG concentration, followed after 1 hour by a decline. A gradual decrease in total glutathione concentration took place throughout the 3-hour experiment. 
and $0.1 \mathrm{ml}$. of $1 \mathrm{~N}$ hydrochloric acid were added to $64 \mu \mathrm{M}$, by weight, of the barium salt as supplied by the manufacturer. After solution of the barium salt $0.3 \mathrm{ml}$. of $0.213 \mathrm{M}$ sodium sulfate was added, and the barium sulfate precipitate removed by centrifugation. The supernatant was neutralized with $0.1 \mathrm{ml}$. of $1 \mathrm{~N}$ sodium hydroxide. The other substrates and the coenzymes were dissolved directly in water. Fructose diphosphate was not entirely soluble in $0.032 \mathrm{M}$ concentration and was used as a suspension. The materials were assumed to be entirely pure as supplied by the manufacturer, and the yield in preparation was assumed to be 100 per cent, except in the case of DPNH and TPNH, the concentrations of which were measured spectrophotometrically.

\section{EXPERIMENTAL AND RESULTS}

\section{The glutathione instability of sensitive red cells}

One-ml. aliquots of blood from 5 sensitive and 7 non-sensitive individuals have been incubated with $5 \mathrm{mg}$. acetylphenylhydrazine for 2 hours. The GSH content of the red cells of non-sensitive individuals changed very little while that of sensitive individuals fell markedly (11). The subsequent experiments were designed to clarify the mechanism of the destruction of the GSH and the mechanism of the difference in the response of drug-sensitive and drug-non-sensitive cells to incubation with acetylphenylhydrazine.

\section{The fate of the GSH of sensitive red cells incu- bated with acetylphenylhydrazine}

One-ml. aliquots of blood from a sensitive (by test) subject were incubated with $5 \mathrm{mg}$. acetylphenylhydrazine using the "glutathione stability test" technique. The reduced (GSH) and oxidized (GSSG) glutathione contents of the red cells were determined initially and after incubation for $40,60,90,120$, and 180 minutes. The results of this experiment are presented in Figure 1. The GSH concentration of the erythrocytes fell rapidly, the characteristic response of sensitive red cells to incubation with acetylphenylhydrazine. The GSSG, however, showed an initial rise, the total glutathione (GSH and GSSG) concentration falling only slightly, indicating that most of the "destroyed" GSH had been oxidized to GSSG. After 1 hour, the GSSG concentration also began to decline. Thus, there was a gradual decline in total glutathione throughout the 3-hour experiment.

\section{The mechanism of the destruction of GSH}

The degree of oxygenation of the sensitive red cell influences markedly the destruction of its GSH content by acetylphenylhydrazine. Oxygen, carbon dioxide, or carbon monoxide have been passed through blood from a non-sensitive individual and GSH stability tests carried out. The stability of the GSH of non-sensitive cells was not affected appreciably by any of the gases used. In contrast, the response of the GSH of sensitive cells to incubation with acetylphenylhydrazine was influenced markedly. The oxygenated sensitive cells showed the characteristic fall in GSH level, but there was very little drop in GSH level in the sensitive cells that had been gassed with carbon dioxide and none when carbon monoxide was used (11). This suggested that hemoglobin might play an important role in mediating the reaction between acetylphenylhydrazine and GSH. Therefore, studies of the effect of hemoglobin on GSH solutions incubated with acetylphenylhydrazine were carried out. ${ }^{2}$

One $\mathrm{ml}$. of a $307 \mathrm{mg}$. per cent (10 mM) GSH solution was added to tubes containing $9 \mathrm{ml}$. of 8 grams per cent, 2 grams per cent, and 0.5 grams per cent oxyhemoglobin, 8 grams per cent methemoglobin, 8 grams per cent cyanmethemoglobin, and 8 grams per cent carboxyhemoglobin, and a tube containing $9 \mathrm{ml}$. of water. The GSH content of 1-ml. aliquots of these mixtures was determined within a few minutes, and 1-ml. aliquots were incubated with and without $5 \mathrm{mg}$. acetylphenylhydrazine at $37^{\circ} \mathrm{C}$ for 2 hours after which time the GSH concentration was measured. The results of this experiment are presented in Table I, which demonstrates that the destruction of GSH by acetylphenylhydrazine does not take place when

2 A complicating factor in this portion of the investigation was that some hemoglobin solutions, especially those which had been stored for more than one week at $4^{\circ} \mathrm{C}$, demonstrated considerable GSH destructive properties. This destructive property is only very slightly influenced by formation of methemoglobin or cyanmethemoglobin from the original solution and therefore does not represent activity of traces of methemoglobin contaminating the oxyhemoglobin solution. By using hemoglobin solutions only several days old, it was possible to avoid, for the most part, the direct effect of hemoglobin solutions on GSH and thus to study the effect of acetylphenylhydrazine-induced destruction of $\mathrm{GSH}$ with a minimum of interference. 
TABLE I

The effect of several hemoglobin compounds on GSH with and without acetylphenylhydrasine

\begin{tabular}{|c|c|c|c|c|}
\hline Hemoglobin compound & $\begin{array}{l}\text { Hemoglobin } \\
\text { concentration* } \\
\text { grams per cent }\end{array}$ & $\begin{array}{l}\text { Mg. per cent } \\
\text { GSH prior to } \\
\text { incubation }\end{array}$ & $\begin{array}{c}\text { Mg. per cent GSH } \\
\text { after } 2 \text { hours } \\
\text { incubation without } \\
\text { acetylphenylhydrazine }\end{array}$ & $\begin{array}{l}\text { Mg. per cent GSH } \\
\text { after } 2 \text { hours } \\
\text { incubation with } 5 \text { mgm. } \\
\text { acetylphenylhydrazine }\end{array}$ \\
\hline \multirow{2}{*}{$\begin{array}{l}\text { Control } \\
\text { Oxyhemoglobin } \\
\text { Oxyhemoglobin } \\
\text { Oxyhemoglobin } \\
\text { Methemoglobin } \\
\text { Cyanmethemoglobin } \\
\text { Carboxyhemoglobin } \\
\text { Acetylphenylhydrazine- } \\
\text { modified hemoglobin }\end{array}$} & $\begin{array}{l}0 \\
.45 \\
1.8 \\
7.2 \\
7.2 \\
7.2 \\
7.2\end{array}$ & $\begin{array}{l}30.7 \\
30.1 \\
27.2 \\
25.1 \\
26.6 \\
30.3 \\
24.7\end{array}$ & $\begin{array}{c}31.5 \\
\overline{-} \\
20.3 \\
16.9 \\
28.7 \\
22.9\end{array}$ & $\begin{array}{r}30.9 \\
29.7 \\
19.5 \\
8.8 \\
14.9 \\
25.4 \\
24.5\end{array}$ \\
\hline & 6.2 & 25.8 & 7.4 & 一 \\
\hline
\end{tabular}

* Measured as cyanmethemoglobin.

these two compounds are mixed in the pure form. Furthermore, the data in this table demonstrate that relatively large concentrations of oxyhemoglobin are necessary to mediate the reaction. Methemoglobin itself destroys only a moderate amount of GSH, and the presence of acetylphenylhydrazine in the system has little additional effect. Cyanmethemoglobin is relatively inert as is carboxyhemoglobin. It is apparent from the data presented that the recovery of GSH in the presence of large amounts of some of the hemoglobin compounds was appreciably less than 100 per cent. This unexplained finding has been quite consistent, although recovery of small amounts of GSH added to whole blood is complete $(12,15)$.

The effect of acetylphenylhydrazine-modified hemoglobin, prepared in such a way as to remove all or most of the acetylphenylhydrazine from the solution (see Materials and Methods), was also determined. One part of $307 \mathrm{mg}$. per cent GSH solution was added to 9 parts of 6.9 grams per cent acetylphenylhydrazine modified hemoglobin (measured as cyanmethemoglobin at $540 \mathrm{~m} \mu$ ). The recovery of GSH was rather poor, only $25.8 \mathrm{mg}$. per cent could be recovered immediately. After incubation for 2 hours at $37^{\circ} \mathrm{C}$, only $7.4 \mathrm{mg}$. per cent could be measured (Table I). Thus, oxyhemoglobin modified by acetylphenylhydrazine possessed the same order of destructiveness toward GSH as did acetylphenylhydrazine in combination with 8 grams per cent oxyhemoglobin. Further studies indicate that the addition of carbon monoxide and of $98 \mathrm{mg}$. per cent sodium cyanide fail to modify its GSHdestructive effect. The absorption spectrum of the approximately 6.9 grams per cent acetylphenylhydrazine-modified hemoglobin solution diluted 1 to 100 in $0.005 \mathrm{M}$ phosphate buffer at $\mathrm{pH} 7.0$ has been measured in the original state, with addition of oxygen, carbon monoxide, sodium hydrosulfite, and sodium cyanide, final concentration $0.0004 \mathrm{M}$. The spectra of these preparations are illustrated in Figure 2 and the absorption maxima

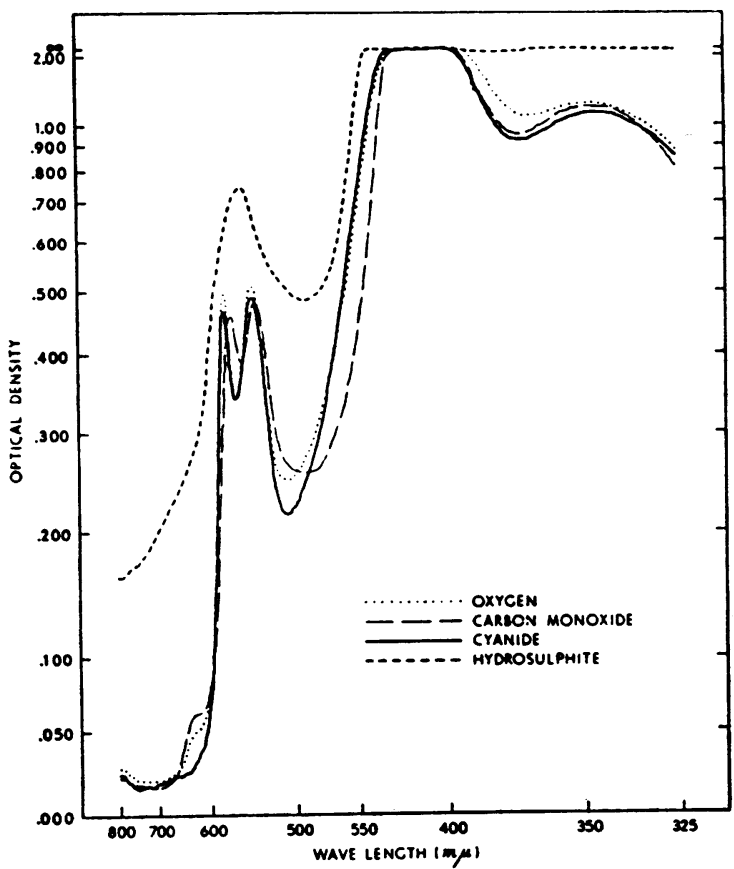

Fig. 2. The Absorption Spectra of Various Derivatives of a Solution of Hemoglobin Which Had Been Modified by Treatment With ACetylphenylhydraZINE (SEe METHOdS)

The spectrum of the unmodified pigment very closely resembled that observed after treatment with oxygen. 
TABLE II

Absorption maxima of "acetylphenylhydrasine modified hemoglobin"

(All measurements were carried out in $.005 \mathrm{M}$ phosphate buffer, $\mathrm{pH}$ 7.0, with the Beckman direct transmittance recording spectrophotometer, Model DK.)

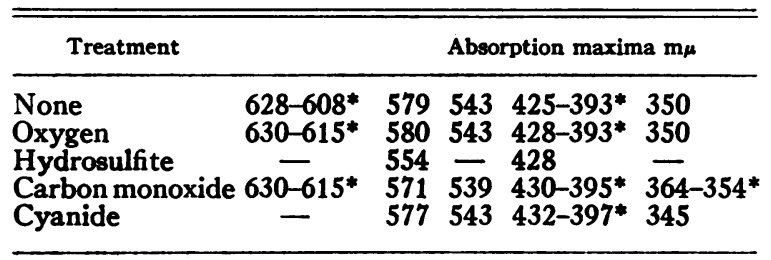

* Plateau, approximate range.

are presented in Table II. The spectra do not differ significantly from those of unaltered hemoglobin except for a small plateau in the 608 to $630 \mathrm{~m} \mu$ region. This disappears on treatment with hydrosulfite or cyanide, and apparently represents a trace of methemoglobin.

\section{The biochemistry of the protection of red cell GSH against the effect of acetylphenylhydrazine}

Early in the course of our studies of the GSH stability test we discovered that if blood samples were allowed to stand at room temperature for 24 hours, non-sensitive red cells lost their capacity to protect their GSH against acetylphenylhydrazine, but that their protective mechanism remained intact if an excess of glucose was added to the blood (11).

Further studies of the dependence of the GSH protecting mechanism on glucose have been carried out. Plasma was removed from the blood of a non-sensitive (Caucasian) donor, and the red cells were washed once in 0.9 per cent sodium chloride solution. A suspension of approximately 50 per cent was made in a saline-phosphate buffer (tonicity $1.0, \mathrm{pH} 7.0)^{8}$ To one portion, 1 part of 0.9 per cent sodium chloride solution was added to 9 parts of suspension; to another portion, 1 part of 5 per cent glucose in 0.9 per cent sodium chloride solution was added to 9 parts of suspension. GSH stability tests were carried out on aliquots of these two suspensions immediately and after incubation for 2 hours and 4 hours at $37^{\circ} \mathrm{C}$. After 4 hours, 1 part of 5 per cent glucose in 0.9 per cent sodium chloride solution was added to 9 parts of the suspension which had been incubated without glucose. A GSH stability test was car-

\footnotetext{
${ }^{3}$ Prepared according to the directions of Ponder (16).
}

ried out immediately and after further incubation at $37^{\circ} \mathrm{C}$ for one and three-quarters hours. The results of this experiment are presented in Figure 3. They demonstrate that glucose is required for the protection of GSH by non-sensitive cells, and that even after incubation for 4 hours without glucose, non-sensitive cells quickly regain their capacity to protect GSH when glucose is again made available.

To determine the effect of a number of other substrates on the ability of red cells to protect their GSH, sensitive (by test) and non-sensitive (Caucasian) cells were washed once in 0.9 per cent sodium chloride solution, and the packed cells were resuspended in an approximately equal volume of saline-phosphate buffer. To aliquots of the red cell suspension the following substrates, dissolved in saline-phosphate buffer, were added in the proportion of 1 part of substrate to 4 parts of cell suspension: glucose, $0.100 \mathrm{M}$; glucose, 0.100 $\mathrm{M}$ with methylene blue, $0.00025 \mathrm{M}$; inosine, 0.100 $\mathrm{M}$; sodium lactate, $0.200 \mathrm{M}$; sodium pyruvate, $0.200 \mathrm{M}$; sodium malate, $0.200 \mathrm{M}$; sodium fumarate, $0.200 \mathrm{M}$; ribose, $0.100 \mathrm{M}$; saline-phosphate buffer control (no substrate). GSH stability tests were carried out in the usual manner. The re-

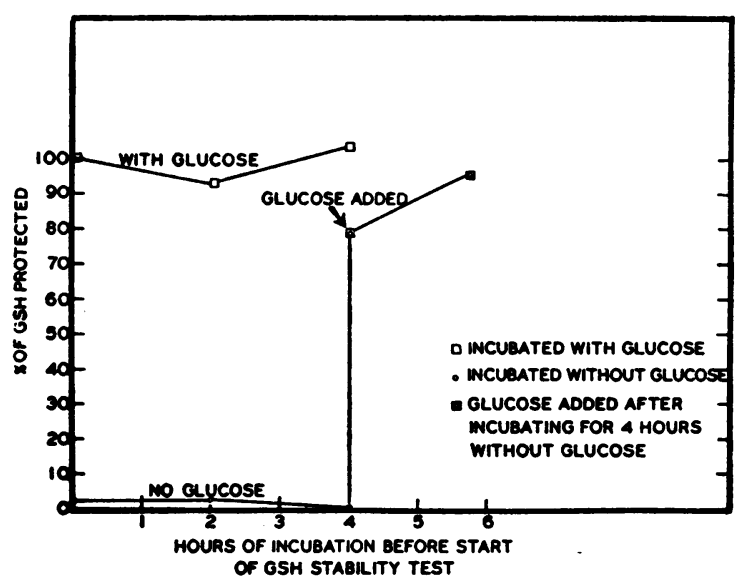

Fig. 3. The Effect of Glucose on the Capacity of Non-Sensitive (Caucasian) Red Cell.s to Protect TheIr GSH Content

A suspension of washed red blood cells from a nonsensitive (Caucasian) subject was incubated with and without the addition of glucose. At intervals GSH stability tests were carried out on aliquots of the suspensions. The cell suspension without glucose rapidly regained its capacity to protect GSH when glucose was added. 


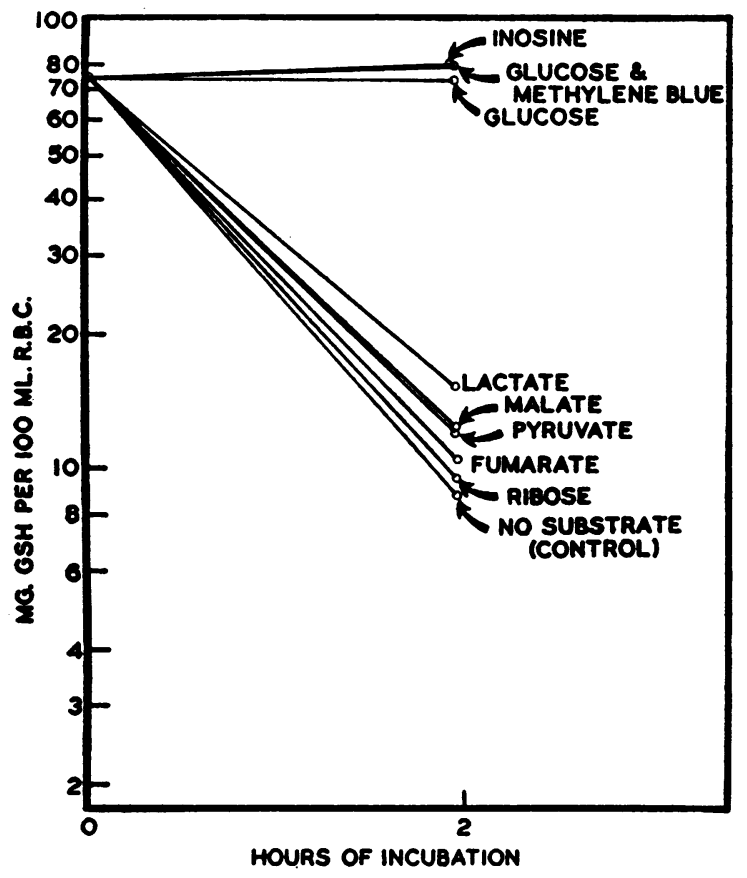

Fig. 4. The Effect of Substrate on the Results of the GSH Stability Test Carried OUt on Erythrocytes from a Non-Sensitive (Caucasian) Subject

The red cells were suspended in saline-phosphate buffer, $\mathrm{pH}$ 7.0. The final concentrations of substrates used were: glucose $0.02 \mathrm{M}$; glucose $0.02 \mathrm{M}$ with methylene blue $0.00005 \mathrm{M}$; inosine $0.02 \mathrm{M}$; lactate $0.04 \mathrm{M}$; pyruvate $0.04 \mathrm{M}$; malate $0.04 \mathrm{M}$; fumarate $0.04 \mathrm{M}$; and ribose $0.02 \mathrm{M}$. Only the glucose and inosine were effective substrates for the protection of GSH. The logarithmic scale emphasizes small differences at low GSH concentrations, a range in which the precision of the method is very limited.

sults of these tests are illustrated in Figures 4 and 5. Although the logarithmic scale employed in these figures emphasizes small differences in GSH levels at low concentrations, it should be stressed that the method of GSH determination used has relatively limited precision at these concentrations. This experiment demonstrates the capacity of non-sensitive cells to utilize glucose and inosine in protecting their GSH and their inability to protect significant quantities of $\mathrm{GSH}$ in the presence of any of the other substrates tested. Sensitive cells were able to protect their GSH only partially with glucose and inosine substrates. ${ }^{4}$ The presence of

1 The degree of protection was somewhat better than when the GSH stability test is carried out on whole blood from sensitive individuals (11). This is probably accounted for by the different suspending medium, which, methylene blue failed to protect significant quantities of GSH.

Because of the impermeability of red cells to phosphorylated sugars (17), and to the enzymes and coenzymes involved in their metabolism, it was necessary to carry out further studies of the enzymatic basis of the protection of red cell GSH in a hemolyzed system.

After establishing optimal conditions, one volume of packed red cells which had been washed once in 0.9 per cent sodium chloride solution was mixed with one volume of a solution containing

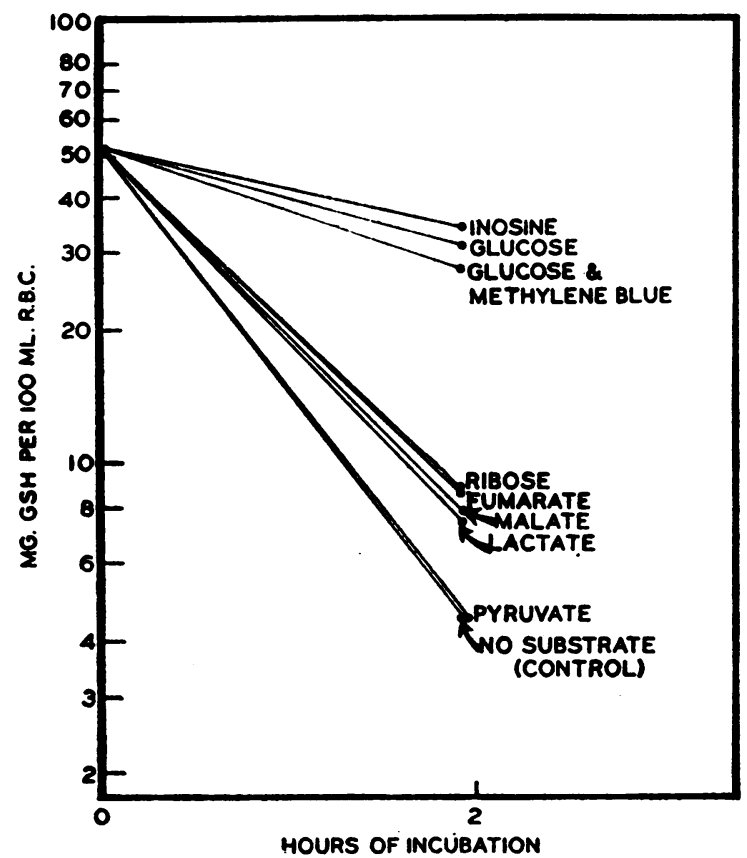

Fig. 5. The Effect of Substrate on the Results of the GSH Stability Test Carried OUt on Erythrocytes Frox a Sensitive Subject

The red cells were suspended in saline-phosphate buffer, $\mathrm{pH}$ 7.0. The final concentrations of substrates used were: glucose $0.02 \mathrm{M}$; glucose $0.02 \mathrm{M}$ with methylene blue $0.00005 \mathrm{M}$; inosine $0.02 \mathrm{M}$; lactate $0.04 \mathrm{M}$; pyruvate $0.04 \mathrm{M}$; malate $0.04 \mathrm{M}$; fumarate $0.04 \mathrm{M}$; and ribose $0.04 \mathrm{M}$. Only the glucose and inosine were effective substrates for the protection of GSH. The greater degree of protection of GSH observed than in the GSH stability test carried out on whole blood is attributed to differences in the properties of the suspended medium. The logarithmic scale emphasizes small differences at low GSH concentrations, a range in which the precision of the method is very limited.

among other things, have a lower $\mathrm{pH}$ and higher glucose concentration than blood plasma. 
$200 \mathrm{mg}$. per cent GSH and $978 \mathrm{mg}$. per cent nicotinamide. Nicotinamide inhibits enzymatic hydrolysis of the pyridine nucleotides (18). The mixture was hemolyzed by freezing in a dry icealcohol bath and thawing. Aliquots were mixed with aqueous solutions of glucose, glucose-1-phosphate, glucose-6-phosphate, 6-phosphogluconate, fructose-6-phosphate, fructose-1,6-diphosphate, inosine, ribose, ribose-5-phosphate, ATP, TPNH, DPNH, DPN, and distilled water, in the concentrations indicated in Table III. One-ml. aliquots of the resultant mixtures were incubated with $5 \mathrm{mg}$. of acetylphenylhydrazine at $37^{\circ} \mathrm{C}$. These were mixed by shaking at hourly intervals. The GSH concentration was measured in the usual manner at the end of a 4-hour incubation period.

The results of experiments utilizing hemolysates from both non-sensitive (Caucasian) and sensitive donors are presented in Table III. As this table shows, no consistent differences were demonstrated between the GSH stability of hemolysates of sensitive and non-sensitive cells. In the limited observations made, both types of hemolysate protected their glutathione in one or more experiments when glucose-1-phosphate, glucose-6-phosphate, 6-phosphogluconate, fructose-6-phosphate, inosine, fructose diphosphate, ribose-5-phosphate, ATP, DPNH, TPNH, and DPN were used as substrates. Glucose and ribose offered virtually no protection when compared with water. It will be noted that there are certain irregular and sometimes paradoxical results in several of the experiments reported. These involve chiefly results obtained through the use of ribose-5-phosphate and fructose-6-phosphate, both of which were obtained as barium salts. Further investigation demonstrated that excess sulfate ion interferes with GSH protection by hemolysates. Furthermore, the results of phosphate analysis and other studies indicate that our assumption of 100 per cent purity was incorrect. Illustrative of our difficulties in obtaining satisfactory phosphorylated compounds to test in the hemolyzed system was the finding that while the first batch of 6-phosphogluconate used adequately protected GSH, a subsequent lot from the same manufacturer (not used in the experiments reported here) differed in physical appearance from the first lot and not only failed to protect GSH but appeared to destroy it. In view of such difficulties it seems prudent to regard the

TABLE III

GSH stability in hemolysates

Conditions: Each hemolysate preparation contains the following final concentrations: packed cell hemolysate 25 per cent; nicotinamide $.02 \mathrm{M}$; added GSH $50 \mathrm{mg}$. per cent.

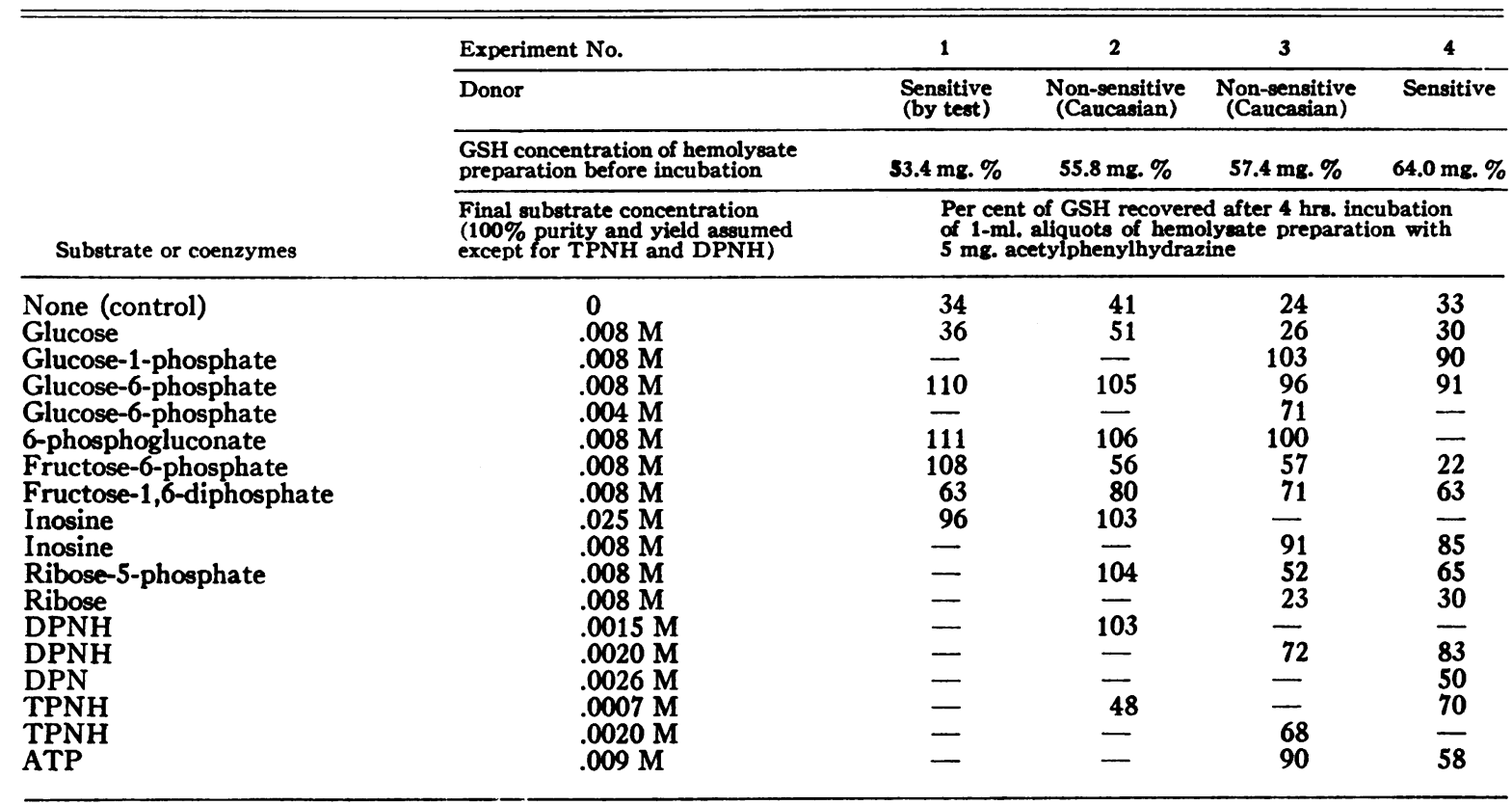


results of our study of hemolysates valid only in a qualitative sense.

In addition to our studies carried out at $37^{\circ} \mathrm{C}$, attempts were made to demonstrate the difference between hemolysates made from sensitive and nonsensitive cells by incubating them with acetylphenylhydrazine at $25^{\circ} \mathrm{C}$. After incubation for 13 hours at this temperature, it was possible to show that the GSH was destroyed in hemolysates to which no glucose-6-phosphate had been added and was protected in the presence of glucose-6phosphate. However, no difference could be demonstrated between hemolysate made from a nonsensitive (Caucasian) and a sensitive (by test) individual.

\section{DISCUSSION}

When drug-sensitive red cells are incubated with acetylphenylhydrazine under standardized conditions, the GSH in these cells is destroyed rapidly. It is apparent from the studies reported here that this destruction of GSH does not depend upon a direct action of acetylphenylhydrazine upon GSH. Oxyhemoglobin, or some other substance in the oxyhemoglobin solution, is required. If oxyhemoglobin itself is the needed substance it is required in concentrations much higher than those which might be expected to suffice if its action were that of a catalyst. It appears most likely that oxyhemoglobin is altered by acetylphenylhydrazine to a form which destroys GSH. The active product has not been identified spectrophotometrically, but it is not methemoglobin or sulfhemoglobin, and, once formed, its activity is not inhibited by cyanide or carbon monoxide.

As the GSH disappears from the red cells, the amount of oxidized glutathione (GSSG) increases. This suggests that the "destruction" of GSH which we observed represents oxidation. After the initial increase in the concentration of red cell GSSG, its concentration also decreased. Although we have not investigated the fate of the GSSG, Flanagan (19) has recently observed that cotton impregnated with silver nitrate turns black when suspended over a blood sample during the glutathione stability test. This finding suggests that the oxidized glutathione may be changed ultimately to hydrogen sulfide.

Since it appears from our findings that the de- struction of glutathione observed in red cells actually represents oxidation, it would seem reasonable to examine the enzyme system concerned with glutathione reduction for the abnormality of sensitive red blood cells. Rall and Lehninger (20) have shown that glutathione is reduced in animal tissues through the action of reduced triphosphopyridine nucleotide (TPNH) and "glutathione reductase." Reduced DPN (DPNH) was found to be ineffective. According to the metabolic schemes that have been proposed for the red blood cell, as reviewed by Bartlett and Marlow (21), Granick (22) and Dickens (23) (Figure 6), TPN is reduced at two stages of red cell metabolism. The first of these is the oxidation of glucose-6-phosphate to 6-phosphogluconate. The second is the oxidation of 6-phosphogluconate to 2-keto-6-phosphogluconate. Recently, Carson, Flanagan, Ickes, and Alving (24) have found that dialyzed hemolysates from primaquine-sensitive individuals differ from those of non-sensitive individuals in their lack of capacity to reduce oxidized glutathione when supplied with a glucose-6phosphate substrate. When a phosphogluconate substrate or TPNH is supplied, however, hemolysates made from drug sensitive cells are as effective as those made from non-sensitive cells in reducing GSSG. This suggests that the glutathione reductase of sensitive cells is intact, but that such cells are deficient in glucose-6-phosphate dehydrogenase activity (Figure 6).

Our observations in intact cells are compatible with the existence of such a metabolic lesion in drug-sensitive cells. They indicate that the striking difference in the GSH levels of sensitive and non-sensitive cells after incubation with acetylphenylhydrazine may well be ascribed to a defect in glucose-6-phosphate oxidation in sensitive cells. It is apparent from the metabolic pathways outlined in Figure 6 that both glucose and inosine may be utilized as substrates for TPN reduction in normal cells. When the GSH of non-sensitive cells is oxidized by acetylphenylhydrazine modified hemoglobin, the GSSG formed could be reduced readily to GSH in the presence of glucose or inosine substrates. If glucose-6-phosphate dehydrogenase activity is reduced in sensitive cells, the pathways of TPN reduction would be interrupted both with glucose and with inosine sub- 


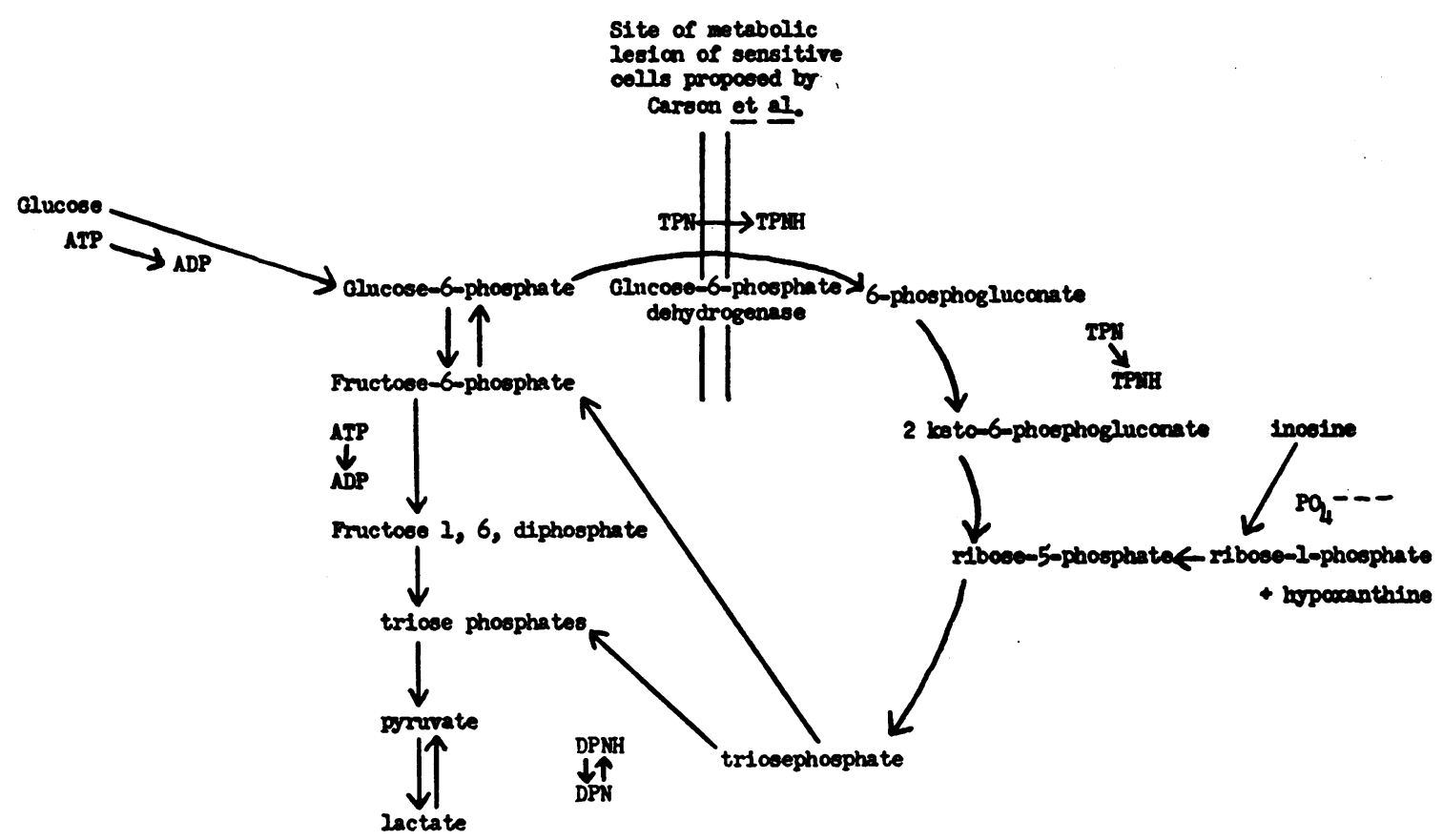

Fig. 6. Carbohydrate Metabolism in the Red Cell: An Abbreviated Scheme Based on Several Sources $(21-23,25)$

Most or all of the reactions are reversible under proper conditions.

strates. When the GSH of sensitive cells is oxidized by acetylphenylhydrazine modified hemoglobin, the rate of GSSG reduction would be impaired. Furthermore, if the protection of red cell GSH depended upon TPN reduction, those substrates that are not utilized for TPN reduction should be ineffective in protecting the GSH of either sensitive or non-sensitive cells. Thus lactate, malate, and fumarate, substrates known to be effective in reducing methemoglobin, presumably through a DPN-linked system $(26,27)$, should be unable to protect GSH either in sensitive or non-sensitive cells. Ribose, which is not metabolized by intact cells (28) should also be inert in the protection of GSH. These predictions were borne out by the experimental data presented in Figures 4 and 5. Glucose and inosine are effective substrates for GSH protection in non-sensitive cells, but in sensitive cells these substrates were less effective. Those substrates, which do not result in TPN reduction, were uniformly ineffective in protecting GSH, both in sensitive and non-sensitive cells.

Although the observations made on suspensions of intact red cells have been helpful in furthering our understanding of the mechanism of drug sensitivity, the scope of the observations has been limited by the impermeability of the red cell membrane to many important metabolic intermediaries. On the other hand, the value of observations we have been able to make on the protection of GSH in hemolysates is impaired by the less physiologic conditions under which they are carried out and by certain technical difficulties that we have described. In the hemolyzed red cells glucose cannot be metabolized (29) presumably due to an absence of ATP and to hydrolysis of the pyridine nucleotides (22). Only by using the phosphoric acid esters of hexoses or ribose as substrates, and by inhibiting coenzyme hydrolysis with nicotinamide, has it been possible to measure the protection of GSH in a hemolyzed system.

Since Carson, Flanagan, Ickes, and Alving (24) have demonstrated a defect in glucose-6-phosphate dehydrogenase activity of sensitive cells, we might have expected hemolysates made from sensitive red cells to fail to protect their GSH when a glucose-6-phosphate substrate was used, while non-sensitive cells might be expected to protect their GSH adequately under the same conditions. 
Our failure to demonstrate such a difference in the present study is probably due to the fact that our preparation is more concentrated than that of Carson and his co-workers (24), probably too concentrated to demonstrate reduced glucose-6phosphate dehydrogenase activity unless the reduction of activity were exceedingly severe. Further dilution of the hemolysate is ruled out by the necessity for a high concentration of hemoglobin to bring about the oxidation of glutathione. The finding that inosine and ribose-5-phosphate are effective in protecting glutathione is consistent with the effect of inosine in intact cells, which we have already discussed. The rather surprising activity of ATP, DPNH and DPN might be explained in terms of enzymatic degradation with the release of a substrate for TPN reduction, rather than in terms of any metabolic activity of the original substance. Enzymes which rapidly hydrolyze ATP to adenosine have been shown to be present in red cell hemolysates $(30,31)$ especially those in which the stroma was damaged by freezing and thawing (32). Adenosine is metabolized to inosine by red cells (33). DPN has been shown to undergo degradation to adenosine-5-phosphate in the presence of an enzyme, nucleotide pyrophosphatase, which is found in various animal tissues (34). The rapid destruction of DPN which occurs in red cell hemolysates is well documented (35), but we know of no effort to demonstrate the presence of nucleotide pyrophosphatase. If this enzyme were present in red cells, inosine could be formed from DPN as well as from ATP. The utilization of inosine as a substrate for GSH protection has already been discussed above. The effectiveness of fructose-6-phosphate, fructosediphosphate, and glucose-1-phosphate is probably due to their conversion to glucose-6-phosphate. The effectiveness of 6-phosphogluconate is probably due to its oxidation to 2-ketophosphogluconate with the reduction of TPN.

At the present state of our knowledge it appears to us that the fall in GSH concentration of sensitive cells incubated with acetylphenylhydrazine and the protection of GSH in non-sensitive cells may be explained as follows : upon incubation with acetylphenylhydrazine the oxyhemoglobin of red cells is altered to a product which oxidizes GSH. In normal cells the GSSG formed is reduced rapidly to GSH through the action of TPN which is reduced when glucose-6-phosphate and phosphogluconate are oxidized. In sensitive cells, a defect in glucose-6-phosphate oxidation limits TPN reduction, both directly and by restricting the amount of phosphogluconate available for further oxidation. The GSSG formed is therefore not reduced effectively and some of it is changed to hydrogen sulfide.

Further studies are required to clarify the role of GSH in the economy of the red cell.

\section{SUMMARY}

1. When primaquine sensitive red cells are incubated with acetylphenylhydrazine under standardized conditions, there is a marked drop in the concentration of reduced glutathione. Under the same conditions, the GSH of non-sensitive cells is unaffected.

2. As the GSH disappears from sensitive red cells, an increase in oxidized glutathione (GSSG) occurs, suggesting that the disappearance of GSH is due to its oxidation. Subsequently, the amount of GSSG in the red cell also diminishes.

3. When GSH is incubated with acetylphenylhydrazine, no destruction of GSH takes place. The addition of oxyhemoglobin in relatively high concentration is necessary for GSH destruction to be observable. Carboxyhemoglobin, methemoglobin and cyanmethemoglobin are much less effective.

4. Non-sensitive red cells are able to protect their GSH in the presence of glucose or inosine, but not in the presence of lactate, pyruvate, malate, fumarate, ribose, or in the absence of substrate.

5. Sensitive red cells are able to protect only a part of their GSH in the presence of glucose or inosine substrate. The addition of methylene blue does not increase their capacity to protect their GSH.

6. Red cell hemolysates containing nicotinamide and added GSH were able to protect their GSH with glucose-6-phosphate, 6-phosphogluconate, fructose-6-phosphate, fructose-1, 6-phosphate, inosine, ribose-5-phosphate, glucose-1-phosphate, ATP, DPN and TPN substrates. No protection was observed with glucose or ribose substrates or when no substrate was present. In the system 
studied, no consistent difference between sensitive and non-sensitive cells could be observed.

7. The results are believed to be consistent with the suggestion of Carson, Flanagan, Ickes, and Alving (24) that the metabolic lesion of drug-sensitive erythrocytes is due to reduced glucose-6phosphate dehydrogenase activity.

\section{REFERENCES}

1. Hockwald, R. S., Arnold, J., Clayman, C. B., and Alving, A. S., Status of primaquine. 4. Toxicity of primaquine in Negroes. J. A. M. A., 1952, 149, 1568.

2. Dern, R. J., Beutler, E., and Alving, A. S., The hemolytic effect of primaquine. V. Primaquine sensitivity as a manifestation of a multiple drug sensitivity. J. Lab. \& Clin. Med., 1955, 45, 30.

3. Beutler, E., Flanagan, C. L., Dern, R. J., and Alving, A. S., The hemolytic effect of primaquine and related compounds. To be published.

4. Dern, R. J., Weinstein, I. M., LeRoy, G. V., Talmage, D. W., and Alving, A. S., The hemolytic effect of primaquine. I. The localization of the drug-induced hemolytic defect in primaquine-sensitive individuals. J. Lab. \& Clin. Med., 1954, 43, 303.

5. Beutler, E., Dern, R. J., and Alving, A. S., The hemolytic effect of primaquine. III. A study of primaquine-sensitive erythrocytes. J. Lab. \& Clin. Med., 1954, 44, 177.

6. Dern, R. J., Beutler, E., and Alving, A. S., The hemolytic effect of primaquine. II. The natural course of the hemolytic anemia and the mechanism of its self-limited character. J. Lab. \& Clin. Med., 1954, 44, 171.

7. Beutler, E., Dern, R. J., and Alving, A. S., The hemolytic effect of primaquine. IV. The relationship of cell age to hemolysis. J. Lab. \& Clin. Med., 1954, 44, 439.

8. Beutler, E., Dern, R. J., Flanagan, C. L., and Alving, A. S., The hemolytic effect of primaquine. VII. Biochemical studies of drug-sensitive erythrocytes, J. Lab. \& Clin. Med., 1955, 45, 286.

9. Flanagan, C. L., Beutler, E., Dern, R. J., and Alving, A. S., Biochemical changes in erythrocytes during hemolysis induced by aniline derivatives. $\mathrm{J}$. Lab. \& Clin. Med., 1955, 46, 814.

10. Beutler, E., Dern, R. J., and Alving, A. S., The hemolytic effect of primaquine. VI. An in vitro test for sensitivity of erythrocytes to primaquine. J. Lab. \& Clin. Med., 1955, 45, 40.

11. Beutler, E., The glutathione instability of drug sensitive red cells. A new method for the in vitro detection of drug sensitivity. J. Lab. \& Clin. Med., 1957, 49, 84.

12. Grunert, R. R., and Phillips, P. H., A modification of the nitroprusside method of analysis for glutathione. Arch. Biochem., 1951, 30, 217.
13. Dohan, J. S., and Woodward, G. E., Electrolytic reduction and determination of oxidized glutathione. J. Biol. Chem., 1939, 129, 393.

14. Drabkin, D. L., Spectrophotometric studies. XIV. The crystallographic and optical properties of the hemoglobin of man in comparison with those of other species. J. Biol. Chem., 1946, 164, 703.

15. Beutler, E., Robson, M. J., and Buttenwieser, E., Unpublished observations.

16. Ponder, E., Hemolysis and Related Phenomena, New York, Grune \& Stratton, Inc., 1948, p. 104.

17. Dische, Z., Untersuchungen über die Bedeutung der Phosphorsäure-ester für den Ablauf und Steuerung der Blutglykolyse. I. Mitteilung; Abbau der Hexosephosphorsäureester zu Triosephosphorsäureester als erste Stufe der Glykolyse. Bildung eines Fructosephosphorsäureester aus Glucose und Glycerinaldehyd durch intakte Erythrocyten. Versuch einer Erklärung der sogenannten Harden-Youngschen Gärungsgleichung. Biochem. Ztschr., 1934, 274, 51.

18. Handler, P., and Klein, J. R., The inactivation of pyridine nucleotides by animal tissues in vitro. J. Biol. Chem., 1942, 143, 49.

19. Flanagan, C. L., Personal Communication.

20. Rall, T. W., and Lehninger, A. L., Glutathione reductase of animals tissues. J. Biol. Chem., 1952, 194, 119.

21. Bartlett, G. R., and Marlow, A. A., Enzyme systems in the red blood cell, Bulletin of the Scripps Metabolic Clinic, San Diego, Calif., 1951, Vol. 2, No. 5.

22. Granick, S., The chemistry and functioning of the mammalian erythrocyte. Blood, 1949, 4, 404.

23. Dickens, F., The significance of the direct pathway for glucose oxidation in The Major Metabolic Fuels, Brookhaven National Laboratory, Symposia in biology No. 5, 1952, p. 134.

24. Carson, P., Flanagan, C. L., Ickes, C. E., and Alving, A. S., Enzymatic deficiency in primaquine sensitive erythrocytes. Science, 1956, 124, 484.

25. Kalckar, H. M., The enzymatic synthesis of purine ribosides. J. Biol. Chem., 1947, 167, 477.

26. Gibson, Q. H., The reduction of methaemoglobin in red blood cells and studies on the cause of idiopathic methaemoglobinaemia. Biochem. J., 1948, 42, 13.

27. Spicer, S. S., Hanna, C. H., and Clark, A. M., Studies in vitro on methemoglobin reduction in dog erythrocytes. J. Biol. Chem., 1949, 177, 217.

28. Dickens, F., Oxidation of phosphohexonate and pentose phosphoric acids by yeast enzymes. I. Oxidation of phosphohexonate. II. Oxidation of pentose phosphoric acids. Biochem. J., 1938, 32, 1626.

29. Warburg O., and Christian, W., Aktivierung von Kohlehydrat in roten Blutzellen. Biochem. Ztschr., 1931, 238, 131. 
30. Garzó, T., Ullman, A., and Straub, F. B., Die Adenosintriphosphatase der roten Blutkörperchen. Acta physiol., 1952, 3, 513.

31. Clarkson, E. M., and Maizels, M., Distribution of phosphatases in human erythrocytes. J. Physiol., 1952, 116, 112.

32. Székely, M., Mányai, S., and Straub, F. B., Die Wirkung der Hämolyse auf den Stoff wechsel der roten Blutkörperchen beim Menschen. Acta physiol., 1953, 4, 31.
33. Gabrio, B. W., Finch, C. A., and Huennekens, F. M., Erythrocyte preservation: A topic in molecular biochemistry. Blood, 1956, 11, 103.

34. Kornberg, A., Reversible enzymatic synthesis of diphosphopyridine nucleotide and inorganic pyrophosphate. J. Biol. Chem., 1950, 182, 779.

35. Schlenk, F., Enzymatic reactions involving nicotinamide and its related compounds. Advances in Enzymol., 1945, 5, 207. 